Ann. Biol. anim. Bioch. Biophys., I975, 15 (2), 263-27I.

\title{
THE CONTROL \\ OF REPRODUCTION IN THE NURSING COW WITH A PROGESTAGEN SHORT-TERM TREATMENT
}

\author{
D. CHUPIN, J. PELOT and J. THIMONIER \\ Station de Physiologie de la Reproduction, \\ Centre de Recherches de Tours, I. N.R. A., \\ Nouzilly, 37380 Monnaie (France)
}

\section{SUMMARY}

Post-partum anoestrus is pronounced in the nursing cow of the Salers breed. At the time when breeding commences, 60 days after calving, only $20 \mathrm{p}$. I 00 of females have an active corpus luteum. Treatments to be used seek to induce, rather than to block cyclic activity.

Different progestagens and methods of administration have been tested. Subcutaneous implants of SC 2 Ioog (Searle) have proven the most efficient and the most practical.

Three treatment parameters condition this efficiency :

- Duration of treatment : calving rate $=62$ p. Ioo for a treatment of 7 days, 57.5 p. Ioo for 9 days, $45.6 \mathrm{p}$. Ioo for I I days and 26.0 p. Ioo for I3-I 5 days.

- An injection of oestradiol valerate on the first day of treatment. For a given duration of treatment ( 13 days) the calving rate is increased from 19.7 p. roo to 52.8 p. 100 .

- The dose of progestagen : $6 \mathrm{mg}=43.4 \mathrm{p}$. I00, $9 \mathrm{mg}=55.5 \mathrm{p}$. I0o, I $2 \mathrm{mg}=60.3 \mathrm{p}$. Iо0. An implant containing $6 \mathrm{mg}$ supplemented with an injection of $3 \mathrm{mg}$ at the beginning of treatment gives same results as $9 \mathrm{mg}$ ( 55.5 p. Ioo calving rate).

All these results were obtained after injection of Soo IU PMSG on the last day of treatment.

The most pronounced period of sexual inactivity in cattle occurs after parturition in the cow nursing her calf (OXENREIDER, I968 ; SHORT et al., I972). Environmental conditions and herd management alter the duration of this resting phase (Wiltbank et al., I964; Bellows et al., I972; Turman et al., I964). For cows of the Salers breed in mountainous regions, the long winters, attached stabling and often insufficient hay-based diet produce a lactation anoestrus which is particularly marked. A treatment for the control of reproduction in these nursing cows should thus induce, rather than block, cyclic activity.

During the past 5 years, different progestagens (MAP, DHPA, FGA, Norethandrolone, SC 2roog) and different methods of administration (vaginal sponges, intra- 
muscular injection, oral administration, subcutaneous implants) have been tested. It has been shown that when the duration of treatment is increased, the degree of synchronization increases and the fertility at the induced oestrus decreases.

With intramuscular injections of norethandrolone, the fertility is $66.6 \mathrm{p}$. Ioo after a treatment of ro days, and $52.6 \mathrm{p}$. Ioo after a treatment of $\mathrm{I} 8$ days. In the latter case, the fertility returns to normal at the second oestrus (CHupIN et al., I974 b). With FGA given orally, a very good oestrus synchronization is obtained, and calving rates of 45.2 and $52.7 \mathrm{p}$. Ioo after systematic insemination, with treatments of I 8 and Io days respectively (CHUPIN et al., I974 a). But in all these cases, treatments are costly in terms of labour (norethandrolone in daily injections) or product (oral FGA, $30 \mathrm{mg} /$ day).

\section{I. - MATERIAL AND METHODS}

A total of I 425 nursing cows of the Salers breed were treated during 4 years of experimentation for the development of treatments based on subcutaneous implants containing SC 21009 .

The existence of ovarian activity has been estimated using as criteria, the circulating levels progesterone at the beginning and end of treatment for the control of oestrus. All cows with a level of progesterone greater than $0.5 \mathrm{ng} / \mathrm{ml}$ plasma at least once were considered cyclic.

Different doses of progestagen and durations of implant contact were tested.

Doses : $6 \mathrm{mg}, 9 \mathrm{mg}$ and $18 \mathrm{mg}$ in implant form and $6 \mathrm{mg}$ in implant form supplemented with an intra-muscular injection of $3 \mathrm{mg}$ of SC 2 roog. day o.

Durations : Implants were left in place for 7, 9, I I, I3 and 15 days, the day of insertion being

Treatments of 7,9 and I I days, and a part of those lasting I 3 days, were completed by an injection of $5 \mathrm{mg}$ of oestradiol valerate in the first day of treatment. On the last day, all cows received 800 IU PMSG.

Different schemes of insemination were tested : insemination with oestrus detection, 3 systematic inseminations at 36,60 and 84 hours, or 36,48 and 60 hours after the end of treatment, or 2 systematic AIs 48 and 72 hours alter the end of treatment.

Fertility is always expressed as calving rate, compared with number of cows treated. It is calculated either for inseminations effected at the induced oestrus, or for the inseminations effected at the induced oestrus plus those at the eventual returns to oestrus (this corresponds to a calving period of 30 days).

\section{II. - RESULTS}

$$
\text { A. - Cyclicity }
$$

Table I shows that depending on the post partum interval, I3-33 p. Ioo of cows were cyclic, according to the criterium, progesterone level on the first and last days of treatment.

\section{B. - Degree of synchronization}

The degree of synchronization varied according to the treatment (68.9-93 p. Ioo of cows were in oestrus in the $\mathrm{I} 44$ hours following implant removal for treatments with $6 \mathrm{mg} \mathrm{SC} 2 \mathrm{IOOg}$ for I I days, or ${ }^{\prime} \mathrm{I} 2 \mathrm{mg}$ for 9 days, respectively). A maximum of females in oestrus is always observed between 36 and 72 hours after implant removal : 58.9-85.9 p. Ioo of cows were observed in oestrus during this period (table 2 ). 


\section{TABLE I}

Ovarian activity of nursing cows at the beginning of oestrus synchronization treatment

(February-May)

\begin{tabular}{|c|c|c|c|c|}
\hline $\begin{array}{l}\text { Interval between calving } \\
\text { and treatment (days) }\end{array}$ & 40 & $41-50$ & $51-70$ & $71-90$ \\
\hline Number of cows & 217 & 149 & 200 & 57 \\
\hline Cycling cows $(\%)$ & 12.0 & 21.5 & 28.0 & 33.3 \\
\hline
\end{tabular}

Two blood samples at 8 days interval for progesterone assay

$$
\begin{aligned}
& >0,5 \mathrm{ng} / \mathrm{ml}=+ \\
& <0,5 \mathrm{ng} / \mathrm{ml}=-
\end{aligned}
$$

cycling cows $=++$

$$
+
$$

non cycling cows $=-\ldots$

TABLE 2

Oestrus synchronization with SC 21009 subcutaneous implants effect of progestagen dose and treatment duration

(maximum percentage of oestrus in a $4^{8}$ hour period)

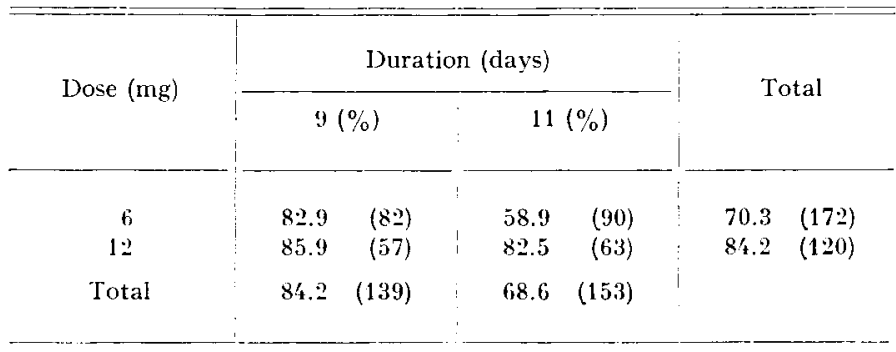

( ) Number of cows 


\section{C. - Fertility at the induced oestrus}

The fertility is comparable regardless of the insemination regime, as shown in table 3, for a given type of treatment ( $22 \mathrm{mg}, 9$ days). We have grouped the results independantly of the insemination regime. Under these conditions of induction of oestrus and ovulation in nursing cows, three principal parameters associated with the treatment influence the efficiency of SC 2 roog implants :

- the length of time the implant remains in place,

- the injection of oestradiol valerate on the day the implant is inserted,

- the dose of progestagen.

TABLE 3

Effect of the scheme for systematic insemination

\begin{tabular}{|c|c|c|c|}
\hline & No. & $\frac{\text { No. calving }}{\text { No. inseminated }}$ & $\frac{\text { No. calving }}{\text { No. treated }}$ \\
\hline AI at observed oestrus & 57 & 64.7 & 57.4 \\
\hline 3 AI-systematic, $3(;-60-8)^{\prime} \mathrm{h}$ & 53 & 58.11 & 58.0 \\
\hline 2 AI-systematic, $18-72 \mathrm{~h}$ & $3 \because 0$ & 60.3 & 60.3 \\
\hline
\end{tabular}

r. Duration of treatment and infuence of an injection of cestradiol valerate.

Increasing the duration of treatment diminishes the fertility at the induced oestrus (table 4) : 56.5 p. Ioo of births for treatments of 9 and I I days, against 28.9 p. Ioo for treatments of $I_{3}$ and $I_{5}$ days. This comparison is complicated, however, due to the injection of oestradiol valerate at the beginning of the 9 and II days treatments, and not for those of $I_{3}$ and $I_{5}$ days (WILTBANK and KAsson, I968; Chupin et al., I974 a). The importance of this injection is shown by comparing two groups where the duration of treatment was the same ( 13 days) with and without oestradiol valerate injection on the day of implant insertion (table 5) : birth rates 45.8 p. Ioo $v s 26.9$ p. Ioo respectively. Thus, part of the effect of the duration of treatment analysed above can be attributed to the action of oestradiol valerate.

TABIE 4

Infuence of treatment duration with SC 21009 subcutaneous implants and of oestradiol valerate injection on fertility (calving rate) at synchronized oestrus (Salers and Aubrac breeds)

\begin{tabular}{ccc} 
Treatments & & \\
Caiving rate \\
$9-11$ days with oestradiol valerate & $56.5 \quad(161)$ \\
$13-15$ days without oestradiol valerate & $28.9 \quad(166)$ \\
\hline
\end{tabular}

( ) Number of cows 
TABLE 5

Infucnce of oestradiol valevate on fertility (calving rate) at synchronized oestrus after removal of $S C 21009$ implants : treatment duration $=13$ days (cows and heifers of mixed breeds)

(From Chupis et al., $197+$ c)

\begin{tabular}{ccc} 
Treatment & $\begin{array}{c}\text { Percentage of calving at } \\
\text { synchronized oestrus }\end{array}$ \\
With oestradiol valerate & & \\
Without oestradiol valerate & & \\
\hline
\end{tabular}

2. Dose of progestagen and duration of treatment.

Factors likely to improve fertility, in particular the dose of progestagen and the duration of treatment (for times less than or equal to II days) have been studied more closely (table 6).

TABLE 6

Influence of treatment duration

(SC 21009 implants + oestradiol valerate on first day) and of progestagen dose on fertility (calving rate) at induced oestrus

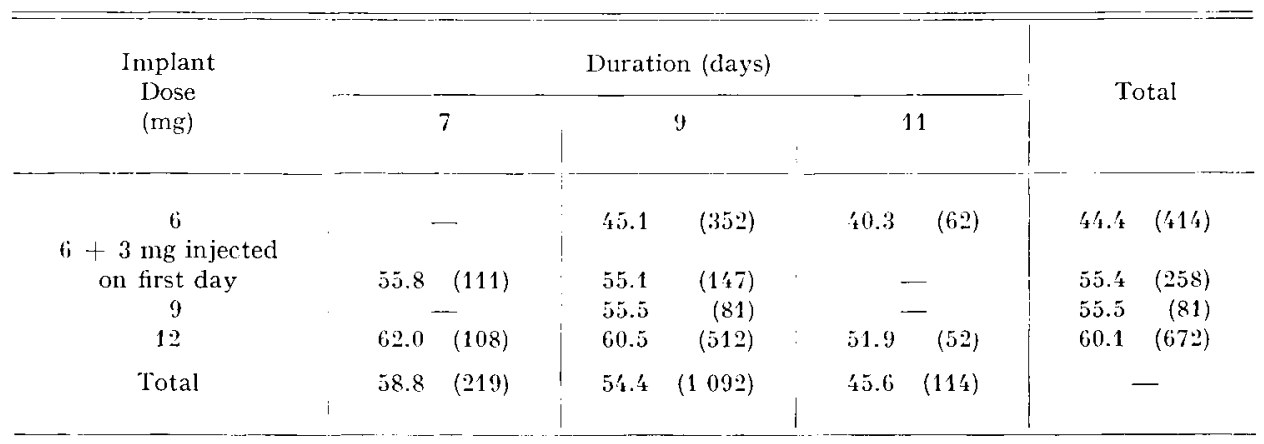

( ) Number of cows.

Fertility increases with the dose (from 6 to $\mathrm{I} 2 \mathrm{mg}$ ) and decreases with the duration of treatment (from 7 to I I days) : the highest calving rate is obtained with $\mathrm{I} 2 \mathrm{mg}$ for 7 days $(62 \mathrm{p}$. IOO) and the lowest with $6 \mathrm{mg}$ for II days $(40.3 \mathrm{p}$. IOO $(\mathrm{P}<0.0 \mathrm{I})$. An implant containing $9 \mathrm{mg}$ SC 2 Ioog, or an implant containing $6 \mathrm{mg}$ supplemented with an injection of $3 \mathrm{mg}$ at the beginning of treatment, gives intermediate results $(55.5$ p. IOo). Whatever the duration, the difference in fertility is significant $(P<0.0 I)$ between doses of 6 and $\mathrm{I} 2 \mathrm{mg}$, and $(\mathrm{P}<0.05)$ between doses of 6 and $9 \mathrm{mg}$ (sum of 
$9 \mathrm{mg}$ implant and $6 \mathrm{mg}$ implant $+3 \mathrm{mg}$ injection). Whatever the dose, the difference between treatments of 7 and II days approaches significance $(\mathrm{P}>0.05)$.

All results presented here were obtained after an injection of PMSG at the end of treatment. The effect of this injection in nursing cows has been shown previously, in particular, its beneficial influence on fertility. After treatment with norethandrolone as intramuscular injections, we obtained a birth rate of $37.5 \mathrm{p}$. roo in the group without PMSG, against 53.I p. Ioo in the group injected with PMSG (CHUPIx, unpublished).

\section{D. - Fertilization at returns to oestrus}

The cumulative percentage of females giving birth over a period of 30 days is relatively low (70 p. roo approx.) (table 7 ). As with the fertility at induced oestrus, an effect of the dose of progestagen is seen $(6 \mathrm{mg}$ vs $\mathrm{I} 2 \mathrm{mg}, \mathrm{P}<0 . \mathrm{OI})$. On the average, only 27 p. Ioo of females not fertilized at the induced oestrus become pregnant in the 30 days which follow.

TABLE 7

Calving rate over a 30 day period

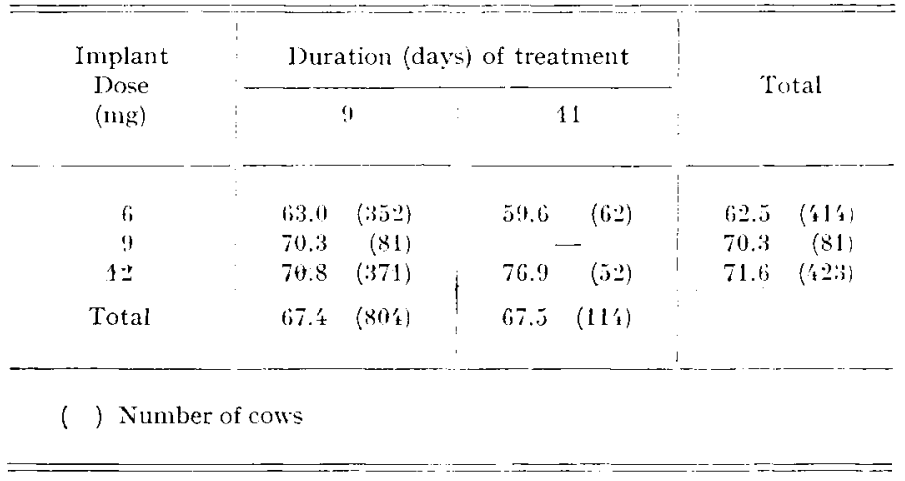

III. - DISCUSSION

\section{A. - Resumption of ovarian activity}

The resumption of ovarian activity after calving is delayed in the nursing cow. The race and the conditions of herd management can influence this lactation anoestrus. In the case of the herds considered in this study, this may be due either to a characteristic of the Salers breed or to an insufficiency regarding alimentation or environment (very gloomy stabling). The importance of these factors has been shown by TURMAx et al., (I964), WiLtBank et al., (I964) OXENREIDER and WAGNER (I97I), and BeLLows et al., (I972). The importance of lighting conditions in stables during the winter period was shown by DEAS (I97I) : by maintaining the stables illuminated for 22 hours per day, he reduced the problems relating to fecundity. Thus, when the animals are put 
to pasture, this represents a very powerful stimulus. We have observed (PELOT and Chupis, unpublished) a difference in the level of cyclic nursing cows of between 2I p. Ioo before putting them to pasture, and $8 \mathrm{I}$ p. Ioo afterwards.

\section{B. - Effect of the dose of progestagen and the duration of implant contact}

Maximum efficiency of SC 2 roog implants was obtained in experiments described here after treatments of short duration, using a high dose of SC 2 roog. The synchronization of oestrus was at a maximum after a treatment of $12 \mathrm{mg}$ for 9 days. The fertility at the induced oestrus was maximal with a treatment of $12 \mathrm{mg}$ for 7 to 9 days.

The necessity of reducing the duration of treatment with progestagens from I6I 8 days to 9-II days has been shown previously (WILTBANk et al., I97I ; ChUpin et al., I97I ; KNox et al., I972; CHUPIN et al., I974 b). The results presented here show that this increase in fertility associated with a decrease in the duration of treatment is likewise observed between II days and 7 days in the nursing cow.

An increase in the dose of progestagen is associated with an increase in the fertility rate at the induced oestrus, regardless of the duration. The most efficient treatments are those which employ a high dose during a short period. In this way, the risk of "leak" of hypophyseal hormones and a progestative influence which are incompatible with an increase in fertility can be avoided simultaneously. Assays of $\mathrm{LH}$ after treatments of 6 or $\mathrm{I} 2$ days in the ewe indicate, effectively, a level of this hormone which is reduced after a long treatment (PELLETIER and CogNIE, I974).

\section{C. - Fertilization at returns to oestrus}

Taking account of the fertility rate observed at the induced oestrus, one can say that the level of females fertilized during the first returns to oestrus is low (on average $70 \mathrm{p}$. Ioo of fertilization in the 30 days after the end of treatment). We have shown that this can be explained in a large part by the conditions of herd management. It is known that in the nursing cow of the Charolais breed, under correct conditions of alimentation (CHUPIN, unpublished), $80 \mathrm{p}$. IOo of animals in which oestrus is induced at the end of treatment, come back into oestrus 3 weeks later if they are not pregnant. The Salers cows of the study presented here are less well fed, and it is possible that a certain proportion of them return to an anoestrus condition after the induced oestrus, thus explaining the low percentage of fertilization at the returns to oestrus noted above.

A second explanation migtht be found in the methods of herd management. The long winter period of attached stabling makes it impossible to detect oestrus precisely, and females not fertilized at the induced oestrus, will only be so when put to pasture with a bull. In the Charolais breed, it has been shown (table 8 ) that it is the interval between the end of treatment and access to a bull which determines the level of females fertilized at the returns to oestrus.

An improvement in the conditions of oestrus detection and the method of stabling is unlikely. On the other hand, the early diagnosis of pregnancy by the assay of plasma progesterone 3 weeks after insemination and the possibilities of using prostaglandin analogues have led us to propose regimes of management which allow systematic insemination of non-pregnant cows at a second induced oestrus. 
In spite of the difficulties of fertilization at returns to oestrus, one obtains, on average, an advance in the calving date of around one month. After this treatment, we obtain on average 43,4 p. Ioo of calvings in January and 27,8 p. IOO in February against $I 6,2$ p. IOO and 35,8 p. Ioo for the same months with traditional husbandry (Chupin and Pelot, I974).

TABLE, 8

Influence of time between end of treatment and introduction of a bull on overall fertility at the subsequent oestruses in a 30 or 60 day period

(Norethandrolone io days. Charolais breed) (From Petit M., I972)

\begin{tabular}{|c|c|c|c|c|}
\hline \multirow{2}{*}{$\begin{array}{l}\text { Interval } \\
\text { end of treatment- } \\
\text { introduction of } \\
\text { the bull } \\
\text { (days) }\end{array}$} & \multirow[t]{2}{*}{$\begin{array}{l}\text { Number } \\
\text { of cows }\end{array}$} & \multicolumn{2}{|c|}{$\begin{array}{l}\text { Percentage of empty cows } \\
\text { following AI at the induced } \\
\text { oestrus and then fertilized } \\
\text { during a period of }\end{array}$} & \multirow{2}{*}{$\begin{array}{l}\text { Percentage of } \\
\text { empty cows at } \\
\text { the end of the } \\
\text { breeding period }\end{array}$} \\
\hline & & 30 days & (j0) days & \\
\hline 18 & $10 \%$ & $4: 2.0$ & 82.0 & 3.8 \\
\hline $25-60$ & 297 & $2-2.5$ & 67.5 & 9.5 \\
\hline No bull & 410 & 20.0 & $\$ 1.0$ & $\geq 1.5$ \\
\hline
\end{tabular}

\section{IV. - CONCLUSION}

With implants of SC 2 IOOg (I2 $\mathrm{mg}$ for 9 days, with $5 \mathrm{mg}$ oestradiol valerate on the first day, and 800 IU PMSG on the last day) a treatment is available allowing the induction of oestrus, followed by normal fertility rates in cows of the Salers breed during lactation anoestrus $(60 \mathrm{p}$. Ioo births after 2 inseminations at the induced oestrus, without prior oestrus detection). The calving rate over a period of 30 days remains low because of management conditions (70 p. Ioo on average). This could be improved to $80-85 \mathrm{p}$. Ioo by systematic treatment of animals found to be nonpregnant after the induced oestrus.

Colloque : Control of sexual cycles in domestic animals
October $27-30,1974$, Nouzilly.

\section{RÉSUMÉ}

\section{CONTROLE DE LA REPRODUCTION CHEZ IES VACHES AILAITANTES} GRÂCE A UN TRAITEMENT PROGESTAGÈNE COURT

L'anœstrus post-partum est très marqué chez la vache allaitante de race Salers. Au moment de la mise en reproduction, 60 jours après le vêlage, seulement 20 p. Ioo des femelles ont un corps jaune actif. Les traitements qui seront utilisés chercheront donc à induire plutôt qu'à bloquer une activité cyclique. 
Différents progestagènes et différentes voies d'administration ont été testés. Les implants sous cutanés de SC 2 roog (Searle) se sont révélés les plus efficaces et les plus pratiques.

Trois paramètres liés au traitement conditionnent cette efficacité :

- La durée du traitement : le taux de mise bas après l'oestrus est de $62 \mathrm{p}$. roo pour un traitement de 7 jours, $57,5 \mathrm{p}$. Ioo pour 9 jours, $45,6 \mathrm{p}$. Ioo pour i i jours et 26,0 p. Ioo pour I3I 5 jours.

- L'injection de valérate d'œestradiol le $I^{e r}$ jour du traitement. Pour une même durée de traitements ( 13 jours) le taux de mises bas augmente de 19,7 à 52,8 p. Ioo.

- La dose de progestagène $: 6 \mathrm{mg}=43,4 \mathrm{p}$. Ioo, $9 \mathrm{mg}=55,5 \mathrm{p}$. Ioo, $12 \mathrm{mg}=60,3 \mathrm{p}$. Ioo. Un implant de $6 \mathrm{mg}$ supplémenté avec une injection de $3 \mathrm{mg}$ donne les mêmes résultats qu'un implant de $9 \mathrm{mg}(55,4 \mathrm{p}$. 100).

Tous ces résultats ont été obtenus en injectant 800 LI de PMSG le dernier jour du traitement.

\section{REFERENCES}

Bellows R. A., Warner I. W., Short R. E., Panish O. F., r972. Gestation feed levels, calf birth weight and calving difficulties. J. Anim. Sci., 35, I85-I86.

Chepin D., Petit M., Mavieon P., i97i. Maitrise de l'ostrus et synchronisation des cycles sexuels chez les bovins. Bull. Tech. Inform. Minist. Agric., 257, I63-174.

Chupin D., Petit M., de Fontalbert Y., Mauleon P., 1974 a. Possibilités d'utilisation d'Acétate de Fluorogestone par voie orale pour synchroniser l'œstrus chez les bovins. Ann. Biol. anim. Bioch. Biophys., 14, 15-19.

Chupin D., Pelot J., Mauleos P., I974 $b$. Comparaison des taux de conception obtenus après insémination artificielle au premier ou au second œstrus après des traitements de synchronisation par la noréthandrolone chez la Vache. Ann. Biol. anim. Bioch. Biophys., 14, 21-26.

Chupin D., Deletang F., Petit M., Pelot J., Le Provost F., Ortavant R., Parez M., MauLEON P., I974 c. Utilisation de progestagènes en implants sous-cutanés pour la maîtrise des cycles sexuels chez les bovins. Ann. Biol, anim. Bioch. Biophys., 14, 27-39.

Chupin D., Pelot J., I974. Synchronisation des chaleurs chez les bovins. Bull. Tech. C. R. Z. I'. Theix. Numéro spécial octobre 1974. VIe journée d'information du "Grenier de Theix ".

DEas D. W., I97I. The effect of supplementary light on winter infertility in cattle.. Iet. Rec., 242.

Knox J. W., RabB J. L., OAkes J. Y., Vincent C. K., 1972. Progestin injection and ear implants for control of oestrus in cattle. J. Anim. Sci., 34, 354 (Abstr.).

OXENREIDER S. L., I 968 . Effects of suckling and ovarian function on post-partum reproductive activity in beef cows. Am.J. Tet. Res., 29, 2099-2102.

Oxenreider S. L., WagNer W. C., ig7i. Fffect of lactation and energy intake on postpartum ovarian activity in the cow. J. Anim. Sci, 33, roz6-103I.

Pelletier J., Cognie Y., cités par Pelletier J., Thimonier J., I975. Interactions between ovarian steroids or progestagens and LH release. Ann. Biol. anim. Bioch. Biophys., 15, 131-r46.

Petit M., I972. Rapport d'activité, services techniques. U. N. C. E. I. A.

Shor't R. E., Bellows R. A., Moodr E. L., Howland B. E., I972. Effects of suckling and mastectomy on bovine post-partum reproduction. J. Anim. Sci., 34, 70-74.

Turman E. J., Smithion L., Pope L. S., Renbarger R. E., Stephens D. F., I964. Effect of feed level before and after calving on the performance of two year old heifers. Minc. Public. Okla. Agric. Exp. Sta., $n^{\circ} P M$ 74, 10-17.

Wiltbank J. N., Rowdex W. W., Ingalls J. E., Zimmerman D. R., 1964. Influence of post-partum energy level on reproductive performance of Hereford cows restricted in energy intake prior to calving. J. Anim. Sci., 23, 1049-1053.

Wítbank J. N., Kassox C. W., rg68. Synchronization of oestrus in cattle with an oral progestational agent and an injection of an estrogen. J. Anim. Sci., 27, II3-II6.

Wiltbank J. N., Sturges J.-C., Wideman D., Lefever D. G., Fallener L. C., ig7t. Control of oestrus and ovulation using subcutaneous implants and oestrogen in beef cattle. J. Anim. Sci, 33, 60o-606. 